\title{
Food Offering Culture at Chinese Rituals in Semarang Chinatown Coastal Community
}

\author{
Catur Kepirianto ${ }^{1}$, Siti Mariam², and Vanessa Febe Purnomo ${ }^{1}$ \\ ${ }^{1}$ Linguistics Department, Faculty of Humanities, Diponegoro University, Semarang - Indonesia \\ ${ }^{2}$ Pendidikan Bahasa Inggris, FITK, Universitas Islam Negeri Walisongo, Semarang - Indonesia
}

\begin{abstract}
Food offering culture in Chinese ritual activities is a form of local wisdom in the religious system and as a medium of communication with Gods and ancestors. Food offerings in Semarang Chinese coastal community rituals are knowledgeable to increase people's awareness of religious consciousness, religious tourism, and culinary culture, especially local language, environmental and cultural identity. The research purpose is to describe various food names and offerings at Chinese ceremonies and ritual activities. It is descriptive qualitative research and refers to the theory of naming systems and meaning as symbols. The research applies observing, collecting, processing, and analyzing data. The research findings describe ritual and cultural ceremonies and celebrations in Semarang Chinatown, such as Chinese New Year, Ceng Beng ritual, festival rebutan, and eating Bakcang celebration. Food offerings imply specific meanings. Kue moho in the Cap Go Meh celebration is a symbol of much luck and fortune. Bakpao symbolizes joy and gentleness. Kue keranjang is a symbol of prosperity. Eating rice cake symbolizes long life and prosperity. Sweets are symbols of the sweet life. Citrus fruits symbolize harmony, and bananas are symbols of prosperity.
\end{abstract}

\section{Introduction}

The culture of offerings at Chinese community rituals is an object of ethnolinguistic research that is still widely open. It also has not been widely used in applied research. The ethnolinguistic approach is used to examine linguistic facts and to reveal the cultural phenomena behind linguistic facts. The results of this study are to describe the names and meanings of Chinese food offerings during ritual ceremonies. The description of Chinese food offerings is expected to have value and benefits, significantly to develop Wisata Kuliner Kopi Semawis [1] (Kopi Semawis culinary tourism) in the Chinatown area of the Semarang Coastal community [2]. Kopi Semawis is an icon and effort to revitalize the Chinatown area as tourism objects, both culinary tourism and historical-cultural tourism and as a modern trading area, as well as a medium for harmonization across culture, language, and ethnicity among Javanese, Chinese, Arabic, and the Netherlands [3].

This applied research hopefully will be helpful to develop Semarang tourism and local culture. The names of food offerings, especially food menus, cakes and fruits, are in the form of names of food related to the Chinese community's ritual activities and the daily consumption needs of the coastal community. Food offerings are rarely produced and traded along with their attributes. Food offerings are sold only in a menu or food without considering 
the values, meanings, and symbolic representations. To be more attractive to the public and tourists in buying food and cuisine menus, it is necessary to know and understand its value and meaning so that the naming of the food and cuisine menus can provide additive value and increase buyers' curiosity to get the special food. The menu and types of food in the offerings are ordinary food and contain unique values, meanings, and functions. The food specialities at a celebration have additive value to increase culinary tourism of local menus and culinary tours of particular foods. In the context of global communication, typical food menus would contribute to developing local tourism promotion. Local and traditional nuances are very important as a unique culinary that is characterized by back to nature. This back to nature feature is essential in the development of culinary tourism in the current era. It is expected to attract and increase domestic and foreign tourists visit Semarang Chinatown.

\section{Method}

This research applied nonparticipant observation and interview methods. To collect the data, the researcher observed the Semarang Chinatown and conducted an in-depth interview with sellers and buyers at Gang Baru traditional market, Semarang Chinatown. The data processing is carried out by classifying, grouping data, and analyzing data. The data of names and meanings were classified according to food, cake, and fruit groups. Classified data then were analyzed to obtain a description of the names and their meanings. The data are presented in descriptive qualitative writing.

\section{Results and Discussion}

Semarang Chinatown is an area located in the city of Semarang. The majority of Chinese descent has inhabited this area since the early 18th century. At that time, the Dutch VOC Company ordered the Chinese in Semarang to settle in a land surrounded by the Semarang River and located not far from the Dutch security. The Dutch suspected that the Semarang Chinese would revolt, so the Dutch Company isolated the Semarang Chinese. They were separated from the natives to prevent carrying out a rebellion against Dutch rule, as was happening in the Geger Pacinan Batavia incident in 1704 [2, 4].

Since the Chinese settled along and around Kali Semarang, the klenteng - Chinese temple has also emerged as a place of prayer, worship, and celebration of Chinese ceremonies. Until now, there are at least 8 (eight) klentengs in Semarang Chinatown. The oldest klenteng in the Chinatown area of Semarang is Sio Hok Bio, founded in 1753 and located at the end of Gang Baru traditional market. The Sio Hok Bio temple is right in front of the Gang Baru traditional market [5][6].

Klenteng is a place of prayer and a place of worship for the Chinese community. It is used to worship Thian (sky), Di (Earth), and ancestors. A temple is a 'sacred meeting' between humans and God and His representatives, the Gods. The temple also functions for social activities and as a meeting place for the neighbourhood community [7]. It is considered the main house for the Chinese people who live around the temple. The temple also functions as a place for ritual activities, ceremonies, and celebrations for holidays.

Chinese ceremonies and rituals in Semarang are held at klenteng or home. Semarang Chinatown cultural activities are manifested in festivals, ceremonies, and celebrations around Semarang Chinatown. These are the cultural and ritual activities of the Chinese people in the Semarang Chinatown coastal community. 
Table 1. Cultural and ritual activities of the Chinese in Semarang Chinatown coastal community

\begin{tabular}{|c|l|}
\hline No. & \multicolumn{1}{|c|}{ Cultural and Ritual Activities } \\
\hline 1. & Lunar New Year (Sin Cia), Chinese New Year \\
\hline 2. & Ceng Beng or Tilik Kubur \\
\hline 3. & Festival Rebutan \\
\hline 4. & Duan Wu or Sembahyang Bakcang \\
\hline
\end{tabular}

At every ceremony or celebration, there are ritual activities and food as the ritual offerings. Ceremonies, ritual activities, and food offerings in the Chinatown area of Semarang coastal community are as follows.

\subsection{Lunar New Year (Sin Cia) as the Chinese New Year.}

\subsubsection{Ritual Ceremony}

Chinese New Year celebrations, often called Sin Cia by the Chinese, are celebrated starting on the 30th of the 12th month and ending on the 15th of the first month on the Chinese calendar. Chinese New Year or Sin Cia historically is a celebration held by farmers in China to welcome the arrival of spring. Chinese New Year comes from the traditions and culture of farmers. The agrarian society in China aims to be grateful for the success of its agricultural activities, harvesting, followed by replanting crops for the next season. Chinese New Year is also interpreted as the emergence of new hope for a better next season and is expected to bring happiness, joy, a symbol of the growth of new fortune and give new hope in every life [8]. New Year is believed to be able to change everything to be new.

To welcome the Chinese New Year celebration, the Chinese community is busy cleaning and painting their houses a few days earlier. This activity is interpreted as getting rid of all bad luck and bad air in the house. Another meaning is to provide freshness and away for good air or aura, as well as great fortune $[5,9]$. The houses are also decorated with red paper cutouts and pasted with words and phrases containing wishes about wealth, long life, happiness, and prosperity.

The Celebrations on the Chinese New Year: Chinese New Year prayers, Prayers to the Creator, and Cap Go Meh

On the night before Chinese New Year, prayers are held to Tian Shi and his ancestors. During Chinese New Year, Chinese people spend the Lunar New Year visiting family and having dinner together. Usually, the child will visit the parents or the older family member. Angpao (red envelopes filled with money) are often given to single persons or unmarried people. Meanwhile, married couples will give red packets to unmarried children.

Moho cake has a cracked shape. The moho cake is a symbol of hockey that is constantly blooming. Bakpao, the pastry of Chinese likes a bun contained with soybeans blend, is a symbol of joy and gentleness. Kue keranjang, a special cake usually produced for the Chinese New Year, symbolises prosperity.

The red colour of angpao - Chinese red envelopes also has a meaning as a medium to exile evil spirits. Angpao is usually decorated with pictures depicting the New Year's zodiac being celebrated. The contents of the red envelop vary, but odd numbers are considered as condolences. Therefore, the contents of the red envelop are required to have an even number. For example, if you want to give 100-thousand rupiahs, you should put two 50-thousand 
notes, because giving 100-thousand rupiahs is not given a piece of 100 -thousand note, which means that the odd number of sheets means condolences, but is given two pieces of 50thousand notes which mean even number, meaning happiness. Chinese New Year celebrations are usually closed with Cap Go Meh, which is the closing of the New Year celebration celebrated 14 days after Chinese New Year.

\subsubsection{Food Offerings}

During Chinese New Year prayers, the food served is adjusted to the target of the prayer. If you pray for the ancestors, the family will serve the favourite ancestor food during his lifetime. In addition, a bowl of rice, vegetables, fruits, and wine or natural water in a small bowl are also served. Mustard sauce (sawi tanah, nasturtium brewed with water) is also served as a dessert after eating.

Foods are essentially served on the altar as offerings at the Chinese New Year.Foods essentially served on the altar as offerings at the Chinese New Year.

- Sam seng or three kinds of meat from the three elements of the earth. Chicken (air), milkfish (sea), and pork (land). Sam Seng is also referred to as a deity to the ruler of the air (Tian Guan), the ruler of the water (Shui Guan), and the ruler of the earth (Di Guan)[10]. Chicken meat is offered to Tian Guan, who has given the blessing of fortune. Fish is offered for Shui Guan to remove disaster, and pork is offered for Di Guan to wash away from sins. When serving fish to the Gods, the selected milkfish is fresh. The thorns left on the milkfish are also symbolised fortune.

- Kue wajik, a diamond cake made of sticky rice, symbolises the closeness and intimate relationship between relatives. Elders of religious leader will give diamonds to a family whose heart is considered harmonious and pleasing..

- Kue $k u$ is a red cake shaped like a turtle shell. This cake symbolizes a long life like a turtle.

- Kue Moho, Moho cake or Hwat Kwee is a cake that is similar to kue mangkok, pink cupcake. Moho cake which has a cracked shape symbolizes a hockey that is constantly blooming.

- Kue Bakpao usually contains green beans or lotus symbolizes joy and gentleness. The texture and color of the buns are expected to bring joy and tenderness to those who eat it.

- Kue Keranjang, special cake produced and prepared for the Chinese New Year is often served and eaten during Chinese New Year celebrations. Kue Keranjang are arranged in stacks from large to small to symbolize prosperity. Of course, the portion of offerings served adjusts to the prosperity level of the celebrating family.

Cap Go Meh celebration is celebrated on the 15th day of the first month by eating lontong opor, dish or cooking of chicken combined with coconut milk as a curry, but it has a yellowish sauce to the chicken meat. Lontong opor symbolizes a fusion of two cultures (Javanese-Chinese) $[11,12]$. Lontong - banana leaf-wrapped and rolled cooked rice is a symbol of longevity, an egg is a symbol of good luck, and the yellowish gravy of opor is a symbol of gold or wealth.

\subsection{Ceng Beng or Tilik Kubur}

\subsubsection{Ritual Ceremony}

Ceng Beng or tilik kubur is a prayer done to visit and honour the ancestors who have passed away by visiting their graves. This prayer is held on April 5th every year because, in Chinese astronomy, the brightest sunshine is on that date.

Ceng Beng celebration takes place ten days before April 5th or ten days after April 5th. At the Ceng Beng festival, the Chinese will visit the ancestor graves in the early morning to 
arrange banquets and offerings. Unlike the daily prayers, the Ceng Beng prayer uses two incense sticks and a pair of red candles. Pilgrims also bring $\mathrm{Kim} \mathrm{Ci}$, paper money which will be burned to provide victuals for their ancestors. At the end of the ceremony, the grave will be marked with Gincua, a silver foil, as a sign that the grave has been cleaned.

\subsubsection{Food Offerings}

Like praying to ancestors during the Chinese New Year, the food served at the Ceng Beng celebration is different from the food served during the Chinese New Year celebration [13]. These are the food offerings at the Ceng Beng ceremony.

- The ancestor favorite foods.

- Sam Seng, three types of cooking ingredients that symbolize life on this earth. At Ceng Beng celebration, the offering cooked season typically is not salted. The three types of dishes are pork (consisting of head, fat, and meat), milk fish, and boiled chicken.

- Ngo Seng offering consists of chicken, pork, milk fish, duck, and crab. Ngo Seng is served by well-to-do families and is usually intended for extended families (in contrast to Sam Seng which is usually eaten by nuclear families). Ngo Seng's dishes are indeed more luxurious, sometimes even using a piece of pork as an offering.

- Rice is put on a plate if the ancestor being visited is a woman and rice is put in a bowl if the ancestor being visited is a man.

- Te Liau, a special sweet for prayer consisting of Tang Kwe, Ang Co, and sugar candy is a symbol of sweet life.

- Kue Ku or Hwat Kwee is a turtle-shaped cake that symbolizes the life of the turtle, which is to have a long life.

- Moho cake or cupcakes are pink and their shape is cracked, symbolizing abundant fortune like the shape of a cracked moho cake.

- Fruits (such as orange symbolizes harmony in the family and banana as a symbol of prosperity) are even in number.

- Sawi tanah sauce (Ku Chay) is as a dessert.

If the ancestor has died for more than two years, the Moho cake can be replaced with a cupcake - Kue mangkok, while the mustard water as a dessert can be brewed without the mustard roots. To know whether the ancestors have finished eating, two coins will be tossed. When two different images appear, it is a sign that the ancestors have finished eating the food served.

\subsection{Festival Rebutan}

\subsubsection{Ritual Ceremony}

Festival Rebutan, often called Cioko, is held to celebrate ancestors who are believed to have come down to the earth to visit their families. This festival, as a combination of celebration and a religious meal, is celebrated on the 15 th day of the 7 th month of the Chinese calendar. In this month, it is believed that the door opens, and spirits descend into the human realm. This month is often called the Month of Ghosts because the ghosts that wander are experiencing hunger. 


\subsubsection{Food Offerings}

Chinese people who celebrate the Festival Rebutan will carry out various activities, such as cooking and giving offerings to their ancestors in the form of various foods by placing the food offerings on the altar or in front of the house. The temples also provide and give offerings to anyone coming to the temple intending to get food. When the family of the ancestor spirit does not give offerings, the family members can come to the temple to get food. This prayer is often held at the temple and is led by Suhu, who leads the ceremony and offers prayers. A variety of food served was placed on the table with a warning that the food should not be touched and the table should not be approached to give time and place for the spirits of ancestors to eat the food served.

The procession of burning money, clothes, and houses from paper is also carried out to equip the ancestor spirits who return to the afterlife. This festival is called the Festival Rebutan because after the ceremony is over and the gong is sounded, the participants fight the food and items on the table. During this festival, usually, groceries and food will be distributed to those in need as the form of alms

\subsection{Duan Wu - Eating Bakcang}

The Bakcang or Duan Wu prayer is held on the 5th day of the 5th month of the Chinese calendar. On this day, Chinese people celebrate it by eating Bakcang (glutinous rice and meat wrapped in triangular dried bamboo leaves). This festival is celebrated to commemorate the services of $Q u$ Yuan, who committed suicide into the river in the middle of the fall of the state of Chu. During the ritual ceremony, residents threw rice wraps and other food to prevent the fish from eating $Q u$ Yuan's body. Another tradition is to set up eggs at noon. It is believed that the Yang energy being radiated is so vital that even a raw egg can stand up on that day. In addition, residents throwing food into the river is a historical origin of the dragon boat race, a tradition during the Duan Wu festival. Residents who participate in the competition will climb into dragon boats and beat drums to ward off evil spirits. This becomes the beginning of the tradition of dragon boat races. In Semarang, dragon boat rowing competitions are no longer held, but this dragon boat race was held on the Banjirkanal river in the past.

\section{Conclusions}

The research findings describe ritual and cultural ceremonies and celebrations in Semarang Chinatown coastal community, such as the celebration of Chinese New Year-Sin Cia, ritual activities of Ceng Beng, festival rebutan, and Duan Wu-the celebration of eating Bakcang. Food offerings imply specific meanings. Kue moho in the Cap Go Meh celebration is a symbol of much luck and fortune. Bakpao symbolizes joy and gentleness. Kue keranjang is a symbol of prosperity. Eating rice cake symbolizes long life and prosperity. Sweets are symbols of the sweet life. Citrus fruits symbolize harmony, and bananas are symbols of prosperity. 


\section{References}

1. T. Svarajati. Pecinan Semarang dan Dar-Der-Dor Kota. Semarang. Suka Buku. (2012)

2. A. Budiman. Semarang Riwayatmu Dulu. Jilid Pertama. Semarang. Tanjung Sari. (1978)

3. P. Hariyono. Stereotip dan Persoalan Etnis Cina di Jawa. Semarang. Mutiara Wacana. (2006)

4. Daradjadi. Geger Pacinan 1740-1743: Persekutuan Tionghoa-Jawa Melawan VOC. Jakarta. Kompas Media Nusantara. (2013)

5. S. Poedjosoedarmo, dan J.U. Wolff. Communicative Codes in Central Java. Data Papers Series, 116. Ithaca, New York. Cornell Southeast Asia Program. (2002)

6. C. Kepirianto. 'Codes in Buying and Selling Discourse at Gang Baru Traditional Market Chinatown Semarang'. Summary. Yogyakarta. UGM. (2019)

7. C. Kepirianto. Accommodation Strategy in Buying and Selling Conversations at Gang Baru Traditional Market Chinatown Semarang, in H, 26, 81 (2019)

8. W.M. Collins. Codeswitching Avoidance as a Strategy for Mam (Maya) Linguistic Revitalization in IJAL, 71, 239-276. Chicago. The University of Chicago Press. (2005)

9. F.R. Palmer. Semantics. Cambridge. Cambridge University Press. (1983)

10. M. Ervin-Trip. Sociolinguistics Rules of Address. in Sociolinguistics: Selected Readings. J.B. Pride dan Janet Holmes. (1986)

11. P. Baryadi. Konsep-konsep Pokok dalam Analisis Wacana. in Jurnal Widyaparwa, 57, 1-23. Yogyakarta. Balai Penelitian Bahasa. (2001)

12. J. Holmes. An Introduction to Sociolinguistics. Second Edition. Essex. Pearson Education. (2001)

13. P. Anderson. Concepts of Meaning in Chinese Rituals. in. Cashiers d'Extreme-Asie, 12, 157. (2001) 